\title{
ATENSI ANAK TENTANG MENYIMAK(BICARA) PADA SISWA TAMAN KANAK- KANAK TK BHAYANGKARI KOTA TERNATE
}

\author{
UMIKALSUM ARFA
}

\author{
Dosen PG-PAUD FKIP Universitas Khairun
}

Some problems were faced childreen in attention especially speaking competence because no confindence and spoil. If children want to speak they showed overly emotional, nervous, silent and more spoild. From those problems researher wants to find about children competences in listening and speaking. The methods children language learning can use Child direct speech. monthere, recasting, enchoing, expanding, and labeling.

\section{PENDAHULUAN}

Sudah menjadi bagian dari suatu bahasa yang memiliki aspek yang satu dengan yang lain saling terkait.Keterampilan berbahasa mempunyai empat komponen yaitu: keterampilan menyimak (listening skills), keterampilan berbicara (speaking skills),keterampilan mernbaca (reading skills), keterampilan menulis (writing skills). Setiap keterampilan itu erat sekali berhubungan dengan tiga keterampilan lainnyadengan cara yang beraneka-ragam. Dalam memperoleh keterampilan berbahasa,biasanya kita melalui suatu hubungan urutan yang teratur: mula-mula pada masa kecilkita belajarmenyimak bahasa, kemudianberbicara, sesudah itu kita belajarmembaca danmenulis. Keempat keterampilan tersebut pada dasarnya merupakan suatu kesatuan, merupakan catur tunggal.

Komponen keterampilan bahasa tersebut dapat dikuasai seseorang dengan cara belajar baik di pendidikan formal ataupun nonformal. Pendidikan formal yang dimaksud adalah pendidikan di usia dini, sekolah dasar, dan seterusnya. Sedangkan pendidikan nonformal yaitu pendidikan yang diberikan orang tua terhadap anaknya. Penguasaan dan penggunaan keterampilan berbahasa antara satu anak dengan lainnya berbedabeda.Hal itu tergantung pada bakat anak dan pengaruh pendidikan yang menyertainya.Hal ini terjadi mengingat bahwa berbahasa (menyimak, berbicara, membaca dan menulis) adalah suatu ketrampilan yang harus terus menerus dikembangkan sesuai dengan kebutuhan anak.

Ada berbagai macam masalah yang dihadapi anak dalam menyimak khususnya kemampuan berbicara. Kadang mereka sangat kurang perhatiannya dalam menyimak(berbicara) karena kurang percaya diri dan memiliki sifat yang agak manja. Jika ingin berbicara maka harus menunjukkan berbagai sikap seperti cengeng, gelisah, diam bahkan malu. Dari permasalahan yang muncul diatas peneliti ingin membahas tentang kemampuan anak yang kurang atensi dalam menyimak(berbicara). 


\subsection{Pengertian Berbicara}

\section{KAJIAN PUSTAKA}

Menurut Lioyd M. Hulit dan Merle R. Howard berbicara diartikan sebagai : "Speech is commonly as understood as oral language, and that understanding will serve our purpose well". Maksud dari pengertian tersebut adalah berbicara dapat diartikan sebagai bahasa lisan, dengan maksud agar tujuan berbahasa dapat tercapai dengan baik.Dalam kamus besar bahasa Indonesia, berbicara berasal dari kata "bercakap", kemudian menjadi bicara yang berarti pertimbangan (pikiran). Dalam berbahasa batasan ini susah untuk dipakai karena disamakan antara keterampilan berbicara dengan berbahasa, padahal berbicara merupakan dari keterampilan berbahasa.

Rata-rata pendidik mengatakan bahwa pengembangan bahasa untuk anak adalah terkait dengan kemampuan membaca dan menulis. Pola pikir para orang tua juga demikian, perkembangan bahasa adalah perkembangan anak dalam kemampuan baca dan tulis. Oleh karena itu, orang tua menyerahkan anaknya untuk dapat baca dan tulis di Taman kanak-kanak dan pada akhirnya guru yang bertugas untuk mengajarkan hingga berhasil. Namun ternyata tidak demikian, kemampuan membaca dan menulis anak terbentuk dari kemampuan mendengar dan berbicara. Jalongo mengatakan bahwa kemampuan membaca permulaan merupakan bentuk demonstrasi kemampuan anak untuk memahami pesan oral dalam bentuk mendengar dan bentuk respon yang berkelanjutan (2007: 158).

Menurut Tarigan (1986) berbicara merupakan suatu bentuk perilaku manusia yang mengatakan faktor fisik, psikologis, nuorologis, neorologis, semantik dan linguistik sedemikian ekstensif, secara luas sehingga dapat dianggap sebagai alat manusia yang paling penting dalam kontrol sosial. Menurut Drs. Suhartono dalam bukunya pengembangan keterampilan berbicara anak usia dini dijelaskan bahwa bicara anak adalah suatu penyampaian maksud tertentu dengan mengucapkan bunyi bunyi bahasa supaya bunyi tersebut dapat dipahami oleh orang yang ada dan mendengar di sekitarnya. Berdasarkan beberapa pengertian diatas dapat disimpulkan bahwa berbicara diawali dari mengucapkan bunyi - bunyi bahasa yang digunakan manusia dalam berkomunikasi dan dianggap sebagai alat yang paling penting dalam kontrol social, dengan menggunakan bahasa lisan dalam berbicara, tujuan atau maksud yang diinginkan dapat tercapai.

Setiap kegiatan berbicara yang dilakukan oleh manusia selalu mempunyai maksud dan tujuan tertentu. Ada beberapa tujuan berbicara menurut para ahli, antara lain; menurut Tarigan tujuan utama berbicara adalah untuk berkomunikasi agar dapat menyampaikan pikiran secara efektif, maka sebaiknya sang pembicara memahami makna segala sesuatu yang ingin dikomunikasikan. Maksudnya pembicara harus mampu mengevaluasi efek komunikasi terhadap pendengarnya, dan dia harus mengetahui prinsip-prinsip yang mendasari segala sesuatu situasi pembicaraan, baik secara umum maupun perorangan. Sedangkan Menurut Djago, dkk tujuan pembicaraan biasanya dapat dibedakan atas lima golongan yaitu (1) menghibur, (2) 
menginformasikan, (3) ,menstimulasi, (4) meyakinkan, dan 5) menggerakkan. Berdasarkan uraian di atas maka dapat disimpulkan bahwa seseorang melakukan kegiatan berbicara selain untuk berkomunikasi juga bertujuan untuk mempengaruhi orang lain dengan maksud apa yang dibicarakan dapat diterima oleh lawan bicaranya dengan baik. Adanya hubungan timbal balik secara aktif dalam kegiatan berbicara antara pembicara dengan pendengar akan membentuk kegiatan berkomunikasi menjadi lebih efektif dan efisien.

\subsection{Strategi Pengajaran Berbicara}

Ketika anak tumbuh dan berkembang terjadi peningkatan baik dalam hal kuantitas maupun kualitas. Produk bahasanya secara bertahap meningkat, berawal dari mengekpresikan mimik wajah sebagai cara untuk berkomunikasi. Alat komunikasi berbicara pada anak menggunakan gerakan dan tanda isyarat untuk menunjukkan keinginannya secara bertahap dan berkembang menjadi suatu komunikasi melalui ajaran yang tepat dan jelas.Sekalipun terdapat perbedaan kecepatan dalam berbahasa pada anak. Namun, komponen-konponen dalam bahasa tidak berubah yaitu : Fonologi, Morfologi, Sintaksis, Semantic dan Pragmatik (Nurbiandini, 2005). Perkembangan fonologi berkenaan dengan adanya pertumbuhan dan produksi sistem bunyi, dalam bahasa bagian terkecil dari sistem bunyi tersebut dikenal dengan nama fonem yang dihasilkan sejak bayi lahir hingga 1 tahun. Sedangkan morfologi berkenaan dengan pertumbuhan dan produksi arti bahasa. Pada makalah sebelumnya, telah banyak membahas perkembangan bahasa pada anak yaitu :

- Tahap prelinguistik yang terdiri dari : menangis, mendekut(cooing beharvior), dan mengoceh.

- Tahap linguistic : Pada usia antara 1-2,5 tahun, anak mulai memadukan dua kata. Pada tahap ini, anak dengan cepat memahami arti penting dari bahasa sebagai alat komunikasi. Mereka menciptakan frase seperti "itu buku" , "permenku ", "sayang mama".

- Tahap diferensia yaitu : Pada usia antara 2,5 - 5 tahun. Saat anak mulai tumbuh, pemahaman mereka terhadap system aturan bahasa mulai meningkat. System aturan ini mencakup fonologi, morfologi, sintaksis, semantic, dan pragmatis. Anak makin mampu menghasilkan serangkaian konsonan yang kompleks.

Pada pembahasan kali ini, lebih memfokuskan pada perkembangan berbicara yang merupakan bagian dari perkembangan bahasa. Dalam buku pengembangan ketrampilan berbicara anak usia dini, dijelaskan bahwa tahap perkembangan berbicara pada anak dibagi menjadi 3, yaitu: 1) perkembangan bicara anak pra sekolah, 2) perkembangan bicara kombinatiri, dan 3) perkembangan berbicara masa sekolah (Suhartono, 2005). Untuk detail penjelasan dari masing-masing tahapan adalah sebagai berikut :

1) Perkembangan Bicara Anak Pra sekolah

a) Tahap penanaman

Pada tahap penanaman, anak baru mulai mampu mengujarkan urutan bunyi kata tertentu dan ia belum mampu untuk memaknainya. Contoh 
:mengucapkan papa, mama, minum dll. Namun anak belum mampu memahami kata tersebut.

b) Tahap telegrafis

Pada tahap ini anak sudah mulai bisa menyampaikan pesan yang diinginkanya dalam bentuk urutan bunyi yang berwujud dua atau tiga kata.Yang termasuk tahap ini yaitu anak yang berumur 2 tahun.Contoh : Anak berkata: "adik minum". Maksudnya : bisa berarti "adik haus, minta minum atau adik minum susu lagi, ataupun adiksudah minum tadi"

c) Tahap transformasional

Pengetahuan dan penguasaan kata-kata tertentu yang dimiliki akan dapat dimanfaatkan untuk mengucapkan kalimat-kalimat yang lebih rumit. Anak yang berumur 5 tahun sudah mulai memberanikan diri

untuk bertanya, menyuruh, menyanggah dan menginformasikan sesuatu. Berbagai kegiatan anak dan aktivitasnya dikomunikasikan dan diujarkan melalui kalimat-kalimat. Disini anak sudah mulai berani mentransformasikan idenya kepada orang lain dalam bentuk kalimat yang beragam. Contoh : ketika anak merasa masih kenyang lalu dipanggi untuk makan, maka ia akan berani menolak atau menyanggahnya dengan menggunakan kalimat sanggahan. Kalimat yang mungkin diucapkan beragam. Antara lain : "bu, saya masih kenyang tidak mau makan atau saya sudah kenyang bu, kenapa disuruh makan"

2) Perkembangan Kombinatori

Perkembangan bicara kombinatori anak sudah mampu menggunakan bahasa dalam bentuk negative, interogativ, dan mampu juga menggabungkan preposisi menjadi satu kalimat tunggal.Kalimat - kalimat yang diucapkan anak sudah mampu mengarah pada kalimat pendek dan sederhana. Anak usia 3-5 tahun pada umumnya sudah berani mengatakan tidak jika disuruh sesuatu. Contoh : ibu memilihkan baju, anak tidak cocok maka nak berani mengucapkan "aku tidak mau mamakai baju ini".

Pada perkembangan kombinatori ini anak mulai mampu berbicara secara teratur dan terstruktur pembicaraan anak sudah bisa dipahami oleh orang lain dan anak bisa merespon baik positive maupun negative. Oleh karena itu, orang tua hendaknya memiliki kepekaan dan kepedulian memperbaiki bahasa anak bila anak salah dalam berbahasa.Orang tua juga harus memberi penguatan (reinforcement) jika memperhatikan bicara anak, baik yang bersifat negative ataupun positive.Penguatan positif diberikan pada anak yang berbicara dengan bahasa yang benar. Contoh bentuk pujianya : "pintar anak mama", atau " betul sekali". Penguatan negative diberikan kepada anak jika anak berbicara tata bahasa yang salah.Dapat berbentuk perbaikan maupun pengulangan.Contoh : "coba ulangi lagi", atau "sebaiknya begini".dll

3) Perkembangan masa sekolah

Pada bahasan makalah terdahulu perkembangan bahasa telah dibahas yaitu Pragmatic, Semantic, Morfologi dan sintaksis.Sedangkan 
Menurut nurbiana (2005), dkk. dalam buku metode pengembangan bahasa ada dua tipe perkembangan anak didalam berbicara, yaitu: a) Egosentrie Speech Yaitu terjadi pada anak berusia 2-3 tahun, dimana anak berbicara pada dirinya sendiri pada saat main boneka dan b) Socialized Speech, yaitu terjadi ketika anak sedang berinteraksi pada temannya dan didalam lingkungan. Hal ini berfungsi untuk mengembangkan kemampuan beradaptasi sosial anak. Sedangkan Menurut Vygostky menjelaskan ada 3 tahap perkembangan bicara pada anak yang berhubungan erat dengan perkembangan berpikir anak, yaitu tahap eksternal, tahap egosentris dan tahap Internal. Dengan penjelasan detail sebagai berikut :

1) Tahap eksternal, yaitu terjadi ketika anak berbicara secara eksternal dimana sumber berpikir berasal dari luar diri anak yang memberikan pengarahan, informasi dan melakukan suatu tanggung jawab dengan anak. Contoh :

- Orang dewasa bertanya: "kamu sedang apa?"

- Anak menjawab: "sedang makan"

- Orang dewasa : "mana sendoknya?", dan seterusnya...

2) Tahap egosentris, yaitu dimana anak berbicara sesuai dengan jalan pikirannya dan pembicaraan orang dewasa bukan lagi persyaratan. Contoh : "ini nasi", "ini piring", "ini sendok".

3) Tahap Internal, yaitu dimana dalam proses berpikir anak telah memiliki suatu penghayatan kemampuan berbicara sepenuhnya. Contoh : ketika anak akan menggambar, anak menggunakan pemikirannya sendiri "apa yang akan saya gambar?". "Saya ingin menggambar rumah".

Pada anak usia TK (0-6 tahun), kemampuan berbahasa paling umum dan efektif dilakukan adalah kemampuan berbicara, hal ini sesuai dengan karakteristik umum kemampuan bahasa anak pada usia tersebut. Karakteristik ini meliputi kemampuan anak untuk dapat berbicara dengan baik, contohnya melaksanakan tiga perintah lisan secara berurutan dengan benar, mendengarkan dan menceritakan kembali cerita sederhana dengan urutan yang mudah dipahami, menyebutkan nama jenis kelamin dan umurnya, menggunakan kata sambung seperti: dan, karena, tetapi. Menggunakan kata tanya seperti: bagaimana, apa, mengapa, apa dan kapan.

Dalam proses belajar bahasa, anak memiliki gaya pendekatan yang berbedabeda, dalam bukunya William Ogrady menjelaskan bahwa terdapat dua gaya belajar berbahasa pada anak, yaitu gaya Analtik dan gaya Gestalt. Dapat dijelaskan bahwa dalam gaya Analitik sejak awal berfokus pada kemampuan menganalisa bagian-bagian kecil. Anak yang menggunakan gaya ini akan menghasilkan kata-kata sederhana dan berartikulasi jelas dan spontan. Kemampuan anak untuk meniru secara spontan spontan bahasa orang dewasa biasanya dengan tata bahasa anak sendiri secara bebas. Contohnya : memberi nama orang atau objek (bapak, ibu) atau mengucapkan kata kata sederhana, seperti : atas, bawah, lapar, panas untuk mendeskripkan perasaan mereka dan apa yang mereka inginkan. Sedangkan gaya Gestalt adalah gaya belajar berbahasa anak yang dimulai dengan kemampuan mengingat kata kemudian memproduksi kata-kata tersebut yang berasal dari kosa kata orang-orang dewasa sehari-hari atau melalui penugasan dari orang dewasa untuk menirukan bahasa 
tersebut. Contohnya ketika anak mengucapkan kata "nggak", yang berarti tidak. Jadi dapat disimpulkan bahwa pendekatan anak berbeda-beda. Dari kedua gaya belajar tersebut, secara teori tidak dapat ditentukan mana yang lebih baik, karena masing anakanak berbeda pilihan proses gaya berbicara mereka dan penelitian tentang percakapan kebahasaan terus berkembang berdasarkan hasil observasi para ahli tentang bahasa anak.

Sedangkan untuk proses berbicara, William Ogrady dalam bukunya yang berjudul Barn to talk terdapat istilah speech chain yang diartikan sebagai proses berbicara dan terdiri dari beberapa tahap proses: Tahap pertama, pembicara mengelompokan ide atau pikiran terlebih dahulu. Kemudian diputuskan melalui ekspresi, proses ini terjadi dalam beberapa detik dan merupakan proses yang kompleks. Tahap kedua, pembicara meletakan pesan dalam sebuah rangka pikiran di otak untuk memilih kata-kata apa yang sesuai berdasarkan ide pemikiran pada tahap pertama.Tahap ketiga, otak mengirim perintah malalui syaraf-syaraf (neurol impuls) lalu mengirimkan ke otot-otot pada mulut yang mengeluarkan partikel suara. Tahap keempat, dari mulut mengeluarkan gelombang suara yang akan tersampaikan ke telinga. Tahap kelima, pendengar mengaktifkan sistem pendengaran mereka. Kemudian telinga yang memiliki kapasitas untuk mentransformasi energi getaran partikel udara lalu energi itu berjalan melalui syaraf menuju otak. Tahap keenam, pada akhirnya otak pendengar menganalisa dan mengartikan pesan dari pembicara; memahami apa yang terjadi dari proses pembicaraan tersebut. Pendengar menerima, membuat pola dan menandai isi pesan.

Orangtua dan guru, atau dapat dikatakan orang tua juga berperan sebagai guru dan model bagi anak untuk mencapai kemampuan berbicara yang baik dan benar, bertanggung jawab menyediakan stimulasi dan sarana agar kemampuan berbahasa anak berkembang dengan positif. Sebagai model, yang memberi contoh dan mnengajarkan anak bagaimana cara dan sikap dalam berbicara juga memberi contoh tentang isi pembicaraan, yaitu susunan kata, intonasi, dan kejelasan kata. Cara - cara agar proses belajar berbicara dapat berjalan sesuai dengan rencana, ada baiknya kita mengetahui strategi dalam pengajaran berbicara untuk anak, yaitu faktor-faktor pendukung, hal-hal yang dapat dilakukan orang tua, metode pembelajaran berbicara dan permainan yang dapat mendukung perkembangan berbicara pada anak.

Dari uraian diatas dapat kami simpulkan bahwa metode pembelajaran bahasa anak, yang dalam hal ini spesifik pada berbicara ada beberapa metode yang dapat digunakan.Yang umum digunakan oleh orang tua adalah Child direct speech. Namun kita bisa juga menggunakan metoe lain yaitu :monthere, recasting, enchoing, expanding, dan labeling.Dalam pelaksanaanya, semua metode adalah baik, jika dilakukan dengan benar dan tetap bertujuan untuk mengembangkan keterampilan berbicara seorang anak. 


\section{METODE}

Lingkup Penilaian pada Anak Usia Dini.Kegiatan penilaian pada Anak Usia Dini mencakup seluruh tingkat perkembangan peserta didik dan data pertumbuhan peserta didik. Lingkup kegiatan penilaian pada lembaga PAUD meliputi aspek bahasa anak, khususnya bicara.Pengamatan/ Observasi. Pengamatan adalah pengamatan langsung pada perilaku atau sikap serta pertumbuhan peserta didik, pengamatannya berupa Pengamatan harian terhadap seluruh aspek perkembangan anak yang muncul selama proses pembelajaran, mencatat apa yang diamati, sehingga dapat dijadikan sebagai dasar untuk menilai perkembangan anak.Checklist. Penilaian dengan cara memberikan tanda tertentu pada daftar indikator atau kemampuan yang telah atau belum dicapai anak, Penugasan. Penugasan merupakan teknik penilaian berupa pemberian tugas yang akan dikerjakan anak usia dini dalam waktu tertentu baik secara perseorangan maupun kelompok, dan unjuk kerja.

\section{HASIL DAN PEMBAHASAN}

Salah satu faktor yang memengaruhi seorang anak lamban berpikir adalah atensi yang kurang. Besar kecilnya atensi seseorang memengaruhi prosesbelajar, perilaku, dan hubungan dengan orang lain. Ketika kontrol atensi disesuaikan dengan baik, cara pandang anak terhadap dirinya dan orang tuanya bisa menjadi lebih baik dan benar. Menerima keberadaan anak yang cerdas, namun tidak produktif memang tidak mudah. Orang tua harus sabar dan bijaksana memperlakukan anak yang terusmenerus melakukan kesalahan dan merasa kecewa setelah melakukannya. Kita perlu memberi dukungan sehat kepada anak, sehingga dia tidak selalu merasa gagal. Anak yang merasa diri tidak mampu dan paling bodoh di kelas, adalah anak yang merasa gagal dan rasa percaya dirinya hancur lebur. Anak kita mungkin bersikap biasa saja, tetapi secara psikis mungkin merasa tertekan dan membutuhkan pertolongan. Sebagai orang tua, kita wajib menolong anak-anak yang memiliki kontrol atensi lemah. Itu bukan kerusakan otak, hanya saja kelebihan anak kita akan terlihat kelak. Kita harus tanamkan rasa optimis dan membuat anak merasa dihargai. Kontrol atensi sangat berperan dalam kehidupan sehari-hari. Kontrol atensi harus beroperasi dengan berbagai cara untuk memenuhi kebutuhan tahapan usia yang berbeda-beda. Kontrol energi mental berkembang pesat pada masa bayi, itulah sebabnya bayi yang sulit tidur pada malam hari cenderung mengalami masalah dalam mengembangkan atensi saat mencapai usia sekolah. Sejak kecil mereka tidak terprogram dengan keseimbangan optimal antara tidur dan terjaga.

Saat menginjak bangku sekolah untuk pertama kalinya, beberapa anak dapat merasa bosan karena harus duduk dalam jangka waktu yang lama. Mereka terkadang memilih berjalan-jalan. Pada tahun berikutnya,

umumnya usaha mental mereka sudah terkontrol dengan baik, sehingga anak dapat belajar mengontrol diri dan mau mengerjakan apa yang tidak mereka sukai, tetapi wajib 
mereka lakukan. Seiring dengan bertambahnya usia dan kedewasaan seorang anak, kontrol atensinya semakin kuat.

Perhatian anak kelas satu dan anak taman kanak-kanak cenderung mudah teralihkan oleh suasana di luar kelas yang berisik atau tingkah lakuteman sebangkunya. Namun, di kelas pertengahan hingga akhir SD,kontrol terhadap arus masuk informasi diharapkan sudah lebih berkembang. Anak kelas enam lebih dapat memberi perhatian kepada guru dan pelajaran dalam jangka waktu yang cukup lama, ketimbang anak yang masih kecil. Anak kecil biasanya hanya akan menyimak hingga setengah cerita, setelah itu mereka akan menaruh perhatian pada hal lain, terutama jika jalan cerita tidak menarik baginya. Sementara itu, kontrol output semakin matang selama masa puber. Secara virtual, seluruh fungsi organ tubuh seharusnya berkembang seiring bertambahnya usia. Namun, semakin anak menjadi besar, fungsi kontrol output semakin pelan. Oleh karena itu, agar kontrol output berjalan dengan baik, kita tidak boleh mendesak anak untuk berpikir secara cepat agar mereka bisa lebih reflektif ketimbang impulsif, memikirkan dahulu sebelum bertindak, dan tidak melakukan hal yang pertama kali terlintas dalam pikiran. Hal ini bertentangan dengan sistem pengajaran anak sekolah menengah, yang menuntut anak melakukan tugas secepat mungkin (menulis cepat, berpikir cepat, mengingat seketika, dsb.).

Perhatikan disfungsi lain yang menyertai. Kontrol atensi yang lemah biasanya merupakan bagian dari suatu disfungsi. Jadi, jika orang tua melihat ada masalah kontrol atensi pada si anak, cobalah mencari tahu apakah ada masalah yang lain yang dialaminya. Seorang anak bisamenunjukkan kesenjangan atensi plus defisit bahasa atau atensi plus memori, atau atensi plus bahasa plus pemikiran sosial. Jika hanya problem atensi saja yang diatasi dan masalah yang lain tidak, maka

tidak akan ada banyak kemajuan yang dicapai.Mengertilah bahwa atensi itu rapuh dan rumit. Anak bisa menghadapi masalah kontrol atensi kapan saja, dan faktor-faktor yang memengaruhinya pun sangat banyak. Berbagai penyakit fisik dan kondisi mental berpengaruh secara negatif pada kontrol atensi. Pengamatan kontrol atensi merupakan cara penting untuk mengontrol kondisi anak secara keseluruhan. Tidak adanya atensi merupakan sinyal adanya masalah, menandakan adanya persoalan dalam diri anak, atau antara dia dan lingkungannya.

Beri anak kebebasan untuk melakukan apa yang ia mau. Anak seringkali disalahkan karena mengalami gangguan atensi. Cobalah untuk tidak menyalahkan anak, tetapi katakan kepadanya bahwa dia hanyalah korban dari jaringan otak, maka matanya akan berbinar. Lemahnya kontrol atensi sering dianggap sebagai kemalasan, sikap negatif, dan nakal. Padahal mereka termasuk anak yang berusaha keras untuk berhasil, untuk menyenangkan diri sendiri, dan untuk mendapatkan pujian dari orang tua. Kita harus bersimpati dan memberi dorongan kepada mereka untuk mengatasi masalah kontrol atensi. Hasilnya, mereka akan bangkit dan menunjukkan perbaikan yang nyata. Jadi, mari tunjukkan kepada mereka bahwa kita bukanlah lawan, tetapi kawan mereka. 


\section{KESIMPULAN DAN SARAN}

Kemampuan berpikir seseorang dipengaruhi oleh kemampuan berbahasa yang dimilikinya. Seseorang dapat mengutarakan pendapat dan mengekspresikan perasaannya secara verbal atas sesuatu yang terjadi di sekitarnya, berkat pengetahuan dan kemampuannya berbahasa. Seorang anak mempelajari bahasa dari pengajaran yang ia peroleh melalui proses belajar beinteraksi dengan lingkungannya. Seiring usia dan pengalamannya, kemampuan bahasa anak akan semakin bertambah, karena kemampuan tersebut akan meningkat jika seorang anak melatih keterampilan berbahasanya. Keterampilan berbahasa diperoleh dari proses hubungan yang teratur dan sangat kompleks. Tiap-tiap aspek keterampilan saling berhubungan dan merupakan kesatuan yang utuh. Dimulai pada masa kecil, seseorang belajar menyimak bahasa terlebih dahulu disekelilingnya, baru kemudian ia akan berbicara, kemudian ia akan belajar membaca dan menulis.

Adapun orang tua, guru dan lingkungan sekitarnya haruslah menciptakan suasana belajar yang nyaman khususnya untuk meningkatkan kemampuan bicara hingga anak lebih percaya diri dalam berkomuniksi verbal. Atensi yang baik dan tidak berlebihan membuat anak bisa mandiri dalam berkomunikasi dan tidak merasa kaku.

\section{DAFTAR PUSTAKA}

Djago Tarigan. Pengembangan Keterampilan Berbicara (Jakarta : Depdikbud, 1997 ), hlm.37

Henry Guntur Tarigan, Berbicara Sebagai Keterampilan Berbahasa

(Bandung : Angkasa, 1986), hlm. 15

Henry Guntur Tarigan, Menulis Sebagai Suatu Keterampilan Berbahasa (Bandung : FKSS IKIP, 1981), hlm. 22.

John W. Stanrock, Perkembangan Anak ( Jakarta: Erlangga, 2007 ), hlm. 376.

Nurbiana dini, dkk.Metode Pengembangan Bahasa. (Jakarta : Universitas Terbuka Depdiknas Cet.keenam, 2005), hlm. 3.6

Poerwadarmito. Kamus Umum Bahasa Indonesia (Jakarta : DEPDIKBUD,1990). hlm.114.

Suhartono, Pengembangan Ketrampian Berbicara Anak (Jakarta : Depdiknas, 2005), hlm.48.

William Ogrady. How Children Learn Language. (Cambidge : The United Kingdom At The University Press,2005),hlm.11.

http://id.shvoong.com/writing-and-speaking/copywriting/2330929-teknik-teknik-penilaianpada-anak/ 